УДК 327 (73)

DOI: https://doi.org/10.33782/eminak2019.2(26).302

\title{
ВИТОКИ ТА ЕВОЛЮЦІЯ КОНЦЕПЦІЇ ГЛОБАЛЬНОГО ЛІДЕРСТВА США
}

\author{
Маргарита Лимар \\ Чорноморський національний університет імені Петра Могили (Миколаїв, Україна) \\ e-mail: rita25lymar@gmail.com \\ ORCID: https://orcid.org/0000-0001-9902-2709
}

\begin{abstract}
У статті досліджуються теоретичні витоки концепції глобального лідерства США. Розглядається ї̈ взаємозв'язок з конщепцією світової гегемонії. Аналізується спроможність США чинити якісний вплив на глобальні геополітичні процеси. Пояснюються причини сприйняття США американцями як держави з особливою місією. Доведено, що США ніколи не відмовлялися від світової першості, але з огляду на трансформаційні зміни міжнародної системи обрали курс на досягнення та підтримку глобального лідерства як кращої альтернативи світовій гегемонії.
\end{abstract}

Ключові слова: США, лідерство, гегемонія, конщепція, «Новий світ»

У XXI ст. Сполучені Штати Америки незмінно залишаються одним з глобальних силових центрів, який здійснює переважаючий вплив на світові трансформаційні процеси. США вважають можливість брати безпосередню участь у геополітичному світотворенні своєю по праву, що межує у свідомості самих американців з відчуттям богообраності. Така позиція простежується у висловлюванні президента США В. Вільсона: «Чому Ісус Христос не домігся того, щоб світ увірував у його вчення? Тому, що він обмежився проповіддю ідеалів, але не вказав практичних засобів для їх досягнення. Я пропоную практичну схему реалізації його цілей»1. Вихід держави на безпрецедентний рівень світового значення базується на концепції глобального лідерства, яка підкріплюється специфікою національного менталітету американського народу, що поєднує у собі жагу до експансіонізму та поширення власного бачення щодо засад організації держави та суспільства.

Вивченню феномену світового лідерства США присвячена низка праць таких вітчизняних дослідників як I. Дудко, М. Миронова, І.Погорська, I. Тихоненко, М. Фесенко, А. Худолій, С. Шергін. Серед наукових розвідок російських вчених варто відзначити напрацювання О. Богатурова, О. Ломтєва, О. Панаріна, Т. Шаклеїної. Увага українських вчених зосереджена, здебільшого, на дослідженні трансформацій міжнародної системи та визначенні американського чинника у цьому процесі. На противагу, російські вчені мають переважно антиамериканську позицію, що простежується у більш грунтовному вивченні генези концепцій світової гегемонії та глобального лідерства з метою довести імперіалістичний контекст американського впливу.

Метою статті $\epsilon$ дослідження витоків концепції глобального лідерства США з кінця XIX ст. та її імплементація у зовнішній політиці держави. Визначено такі завдання: окреслити теоретичне підгрунтя концепції глобального лідерства США; проаналізувати співвідношення понять «глобальна гегемонія» та «глобальне лідерство» 3 огляду на їхній взаємозв'язок; визначити місце концепції глобального лідерства в американських зовнішньополітичних настановах XXI ст.

${ }^{1}$ Lloyd G.D. The truth about the peace treaties. Vol. 1. London: Victor Gollancz, 1938. P. 225. 
Ставлення до «американської нації», яка за своєю сутністю поєднує представників етносів і народів із різних частин світу, є дискусійним. Проте, не залишає сумнівів той факт, що американський менталітет відзначається винятковим прагматизмом, який сприяв створенню теорій, закладених в основу й сучасної зовнішньої політики США. Британський письменник і літературний критик Д. Лоуренс зазначав, що «істинна американська душа є суровою, усамітненою, стоїчною душею убивці, яку неможливо розтопити»2. Про суворість американців, їх схильність до жорстокості та расизму йдеться й у монографії Дж. Карні, який наголошує на тому, що «американська мрія» про рівність і численні можливості втрачає свій сенс з огляду на відголоски експансіонізму й імперіалізму XIX ст.3. Власне, ідею величі США підтримували такі дослідники та громадські діячі, як Дж. Барджес, Л. Лоуелл, Дж. Стронг.

Філософ і геополітик О. Панарін зазначав, що від початку конституювання США, або ж узагальнено - Америки, як країни «Нового світу», було відзначено ідеологічним протистоянням решті світу, який «потопав у гріхах». Вкорінене в американській самосвідомості уявлення про США не як про нову державу, що виникла поруч з іншими, а «Новий світ», який у всьому протистоїть «Старому світу», спричинило одвічне прагнення до самореалізації та подальшого світового лідерства на міжнародній арені ${ }^{4}$.

Основи сприйняття США як держави з особливою місією було закладено від початку її заснування та закріплено ще у XIX ст. Ключем до розуміння такої позиції була ідея піднесення англосаксонської раси, яка поєднувала у собі дві високі ідеї: громадянська свобода та чисте духовне християнство. Таким чином, обгрунтовувалося моральне право американців поширювати власне бачення державоустрою та моральних цінностей у світі5. За словами лідера руху «Соціальне Євангеліє», впливового на свій час громадського діяча та письменника Дж. Стронга, світ, в якому вже на кінець XIX ст. не лишилося вільної землі, вступає в епоху расового протистояння, до якого могутня англосаксонська раса була добре підготовлена. За його прогнозами, вона мала просунутися «в Мексику, через Центральну та Південну Америку, на острови в океані, а потім - в Африку й далі»6.

Американський політолог Дж. Барджес розробив програму експансії, що передбачала закріплення протекторату США над Латинською Америкою, островами Тихого Океану та Східної Азії. Зважаючи на геополітичні трансформації протягом багатьох десятиліть, можна побачити, що його ідеї все ж були взяті до відома американськими політиками й імплементовані у зовнішньополітичній діяльності. Вчений виокремлював расовий чинник як основу політичної організації держави, наголошував на винятковості англосаксонської раси, визначав США найбільш політичною державою та покладав на неї обов'язок поширити у світі свою систему, навіть за умови застосування «жорсткої сили» .

\footnotetext{
2 Draper R.P. D.H. Lawrence: The critical heritage. UK: Psychology Press, 1997. P. 221.

${ }^{3}$ Carney J. Nation of killers: Guns, violence, white supremacy: The American Dream become delusion. US: Lulu Press, Inc, 2015. 146 p.

4 Панарин A. Агенты глобализма. Глава III: Американский глобализм. Москва, 2000. URL: http://www.patriotica.ru/books/panar_agents/part1_3.html

${ }^{5}$ Strong J. Our country: Its possible future and its present crisis. New York, NY: The Baker and Taylor Co, 1885. P. 159-160.

6 Ibid. P. 175.

7 Burgess J.W. Vol. 1: Sovereignty and liberty. In Political science and comparative constitutional law. Boston: Ginn \& Co, 1890-1891. 337 p.
} 
США природно були потужною колонізаційною силою, про що зазначав ще у 1899 р. майбутній президент Гарвардського університету Л. Лоуелл, підтримуючи тезу про експансіоністський характер англосаксонської раси. Разом з тим, США, на противагу Центральній Європі, створювали умови для розвитку впевненої у собі людини, не прив'язуючи ії складними адміністративними системами до уряду, що робило «Новий світ» привабливим для емігрантів з Німеччини й інших країн. Успіх США Л. Лоуелл вбачав у політиці надання рівних прав і можливостей новим територіям і колоніям, однакового ставлення до представників різних рас ${ }^{8}$. Таким чином набула імпульсу ідея того, що лідерство $є$ більш схвальним і сприйнятливим, а головне - вигідним для США.

Поступово така ідея стала фоновою для зовнішньополітичної діяльності американських урядів, тож, зважаючи на геополітичні зміни та зміцнення нових потенційних силових центрів, на зміну експансіоністським настроям США поступово прийшло усвідомлення вигідної позиції світового лідера. Слід зазначити, що прагнення до світового лідерства має свої витоки з політики США по досягненню світової гегемонії, реалізація якої була першочерговим завданням періоду холодної війни й одразу після руйнації біполярності. Російський політолог, професор Т. Шаклеїна зазначає, що зовнішньополітична думка США завжди відрізнялася винятковим національно-орієнтованим характером, тому всі концептуальні модифікації вибудовуються на незмінній догмі наддержавності Америки. I в науково-концептуальних працях, і в офіційних документах неприховано захищається аксіоматичне право США на модифікацію глобального порядку та контроль за його дотриманням. Навіть, коли мова йде про єднання заради спільних демократичних цілей, даний процес має американоцентричний контекст 9 .

Вітчизняна американістка, професор І. Дудко пояснює, що очевидний гегемонізм США у період між 1990-ми та початком 2000-х рр. є результатом імплементації низки грунтовних документів, які сформували ядро зовнішньополітичного курсу адміністрацій США по завершенні блокового протистояння. У даному контексті варто відзначити ключовий документ демократичної адміністрації Б. Клінтона - Стратегія національної безпеки на нове століття (1998р.) й основний документ республіканської адміністрації Дж. Буша-мол. - Стратегія національної безпеки США (2002р.). Обидві адміністрації, незважаючи на полярність політичних орієнтацій, заклали у свої стратегії такі спільні принципи: визнання США як світової наддержави; закріплення інтересів США на глобальному рівні; врахування актуальних проблем сучасності та можливостей інших силових центрів у політиці захисту американських національних інтересів; визнання силових методів впливу на міжнародній арені пріоритетними засобами утримання провідних позицій. Окрім того, обидва документи залишають за США право на самостійні дії без попередньої координації з силами союзників задля захисту або досягнення зовнішньополітичних цілей ${ }^{10}$.

Американіст О. Ломтєв розмежовує поняття «світової гегемонії» та «світового лі-

\footnotetext{
${ }^{8}$ Lowell A.L. The colonial expansion of the United States // Atlantic Monthly: A Magazine of Literature, Science, Art, and Politics. 1899. Vol. LXXXIII. № CCCCXCVI. P. 158.

9 Шаклеина Т. Лидерство и современный мировой порядок // Международные процессы. 2015. № 4 (43). С. 6-19.

10 Дудко I. Формування багатополюсного світу в умовах постбіполярності: прогнози і реалії сучасних міжнародних відносин // Сучасна українська політика. Політики і політологи про неї. 2005. Вип. 5. URL: http://lib.chdu.edu.ua/pdf/pidruchnuku/21/44.pdf
} 
дерства». За дефініціями, перше з них він наближає до концепту «розумної сили» 3 переважним домінуванням «жорсткого» компоненту, а друге - до «м'якої сили». На відміну від «світової гегемонії», яка визначається як поєднання двох начал, - панування (силові й економічні ресурси) і впливу (ідеологічні, культурні, інформаційні ресурси), що переходять в управління з неминучими елементами диктату і / або придушення незгодних, - «світове лідерство» передбачає наявність спільних інтересів у лідера та його послідовників, добровільне визнання його авторитету, запозичення його культурних цінностей, політичного й економічного устроїв. 3 точки зору О. Ломтєва, США втрачають свій вплив у світі, закріплюючи за собою першість у фінансових показниках і торгівлі, але не у питаннях промисловості та воєнної моці. Таким чином, «світове лідерство» стає більш доступною формою впливу на міжнародні політичні процеси, аніж «світова гегемонія».11

Протилежну думку щодо вище окресленого питання мають українські науковці М. Фесенко та С. Шергін. Вітчизняний американіст М. Фесенко також підносить роль інформаційно-культурного домінування і ставить його в один ряд з технологічним та економічним впливом. Завершення епохи блокового протистояння не послабило позицій США, які продовжили витрачати на оборону значні кошти, підтримуючи свій статус потужним модернізованим військовим потенціалом. Вплив США підкріплюється новітніми технологічними розробками та залученням до співпраці кращих фахівців оборонної галузі12.

Поєднання переваг у різних сферах впливу надають США виняткову можливість формування військової коаліції глобального масштабу, на зразок тієї, що відповідала за воєнні дії в Іраку, і ще раніше - в Югославії. Військова могутність США спирається на кілька стовпів, до яких можна віднести ядерну зброю, потужне виробництво озброєнь, якісну підготовку кадрів, дипломатичне забезпечення розгалужених союзів, надійну розвідувальну мережу тощо. Окрім того, США мають такий «ресурс» як політичну волю, яка необхідна для уникнення зайвих поступок і захисту власних національних інтересів ${ }^{13}$.

На думку української дослідниці М. Миронової, тенденції до формування багатополярного міжнародного середовища з початку 2000-х рр. змусили США переглянути власну концепцію глобального лідерства. Це було пов'язане із сумнівами щодо спроможності держави нести тягар відповідальності за міжнародні процеси самотужки ${ }^{14}$. Відносно США таку позицію висловив ще наприкінці 1980-х рр. американський політолог П.Кеннеді, який передбачав «перенапруження імперії», що могло призвести до виснаження ресурсів і можливостей глобальної держави, у разі їх невідповідності амбіціям уряду15. У зв'язку з цим, у 1990-х рр. з'явився американський

11 Ломтев А. Эволюция характера мирового порядка и внешнеполитических стратегий его формирования в американской политической науке: дис... к. полит. наук: 23.00.01. Москва, 2011. C. 21-22.

12 Фесенко М. Перспективи збереження лідерства США в постбіполярній міжнародній системі // Американська історія та політика. 2016. № 2. С. 35.

13 Шергін С., Фесенко М. Трансформація взаємодій міжнародно-політичних акторів в умовах послаблення глобального лідерства США // Науковий вісник дипломатичної академії України. 2009. Вип. 16. С. 351.

14 Миронова М.А. Трансформація відносин Європейського Союзу та США в постбіполярний період: дис... канд. політ. наук: 23.00.04. Київ, 2007. С. 42.

15 Kennedy P. The rise and fall of the great powers. Economic change and military conflict from 1500 to 2000. New York: Random House, 1987. P. 515. 
тренд «розумного лідерства», або «прагматичного інтернаціоналізму»16, який залишав за США статус міжнародного лідера, проте переглядав їх права й обов’язки щодо управління світовими процесами. У постбіполярний період США відмовилися від наміру одноосібно нести тягар відповідальності, притаманний традиційній ролі лідера. Тож, зовнішньополітичний курс США було досить влучно визначено колишнім прем'єр-міністром Франції Л. Жоспеном: «існує певна тенденція до гегемонії, яка не обов'язково співпадає з глобальною відповідальністю наддержави»17.

За президентства Б. Обами США відійшли від концепції гегемонізму, розглядаючи можливі варіанти збереження лідерських позицій через співпрацю з найбільш вірогідними за впливовістю потугами. Дане твердження підкріплюється позицією С. Шергіна та М.Фесенка, які висловлюють аналогічну до О. Ломтєва точку зору з приводу зміщення вектору зовнішньої політики у бік лідерства, проте не через нестачу силових ресурсів, а через наміри залишатися першими серед рівних у колі найбільш впливових акторів на світовій арені18.

Розглядаючи питання спроможності США зберігати лідерські позиції у світі, варто враховувати той факт, що країна-лідер має бути здатною керувати світоформуючими тенденціями. Дослідник міжнародних процесів О. Богатуров окреслив наступні критерії для ієрархізації держав-лідерів: потенціал «жорсткої сили», який здатен фізично контролювати слабші країни; економічна могутність як джерело загальної державної моці; та ідеологічний вплив або потенціал «м'якої сили», що спирається на дипломатичний арсенал лідера ${ }^{19}$. США притаманні всі вищезазначені критерії та важелі впливу. Дану позицію підтримують українські американісти І. Погорська та Д. Лакішик, зазначивши ще у 2011 р., що США не відмовляться від глобального лідерства у короткостроковій і середньостроковій перспективах.

3 приходом адміністрації Б. Обами у 2009 р. зусилля США було зосереджено на зміцненні «морального лідерства» через активну діяльність у рамках ключових міжнародних інститутах (НАТО, ООН, МВФ, СОТ) та співпрацю з потенційними світовими лідерами, згідно «Тенденції глобального розвитку 2015» (зокрема, Китаєм, Індією та Росією). Метою Сполучених Штатів залишається попередження можливого формування сили (у т.ч. - коаліційної), яка могла б переважити можливості США²0. Окрім того, зазначений підхід свідчить про домінування «м'якого» компоненту у концепції «розумної сили», яка стала основою для формування зовнішньополітичного курсу Б. Обами.

3 точки зору І. Погорської, єдиним світовим полюсом, який отримав глобальне масштабування, $є$ західна спільнота на чолі із США, статус яких варто трактувати як статус лідера - першого серед рівних, зважаючи на збереження США своєї потужності, що перевищує можливості інших гравців на міжнародній політичній арені, у тому

\footnotetext{
16 Weston Ch. Key US foreign policy interests // Aussen Politik. 1997. No 1. Vol. 48. P. 50.

17 Marcus J. Adjustment, recrimination: Franco-US relations and the new world disorder // The Washington Quarterly. 1998. Spring. P. 31.

18 Шергін С., Фесенко М. Трансформація взаємодій міжнародно-політичних акторів в умовах послаблення глобального лідерства США // Науковий вісник дипломатичної академії України. 2009. Вип. 16. С. 351.

${ }^{19}$ Современная мировая политика: Прикладной анализ. Отв. ред. А.Д. Богатуров. Москва: Аспект Пресс, 2009. С. 161-162.

20 Погорська I., Лакішик Д. Зовнішня політика адміністрації Б. Обами в контексті американського глобального лідерства // Проблеми міжнародних відносин: Зб. наук. пр. Київ: КиМУ, 2011. Вип. 2. C. 185.
} 
числі комбінацій акторів як, наприклад, - ЄС21.

Стратегія національного оновлення та глобального лідерства, оприлюднена Б. Обамою 28 травня 2010 р., закріплювала положення про те, що США залишаються єдиною світовою наддержавою22. Український американіст А. Худолій звертає увагу на те, що саме за Б. Обами концепція глобального лідерства стала однією з детермінант зовнішньої політики США з огляду на промови та документи його адміністрації ${ }^{3}$.

Американський геополітик Зб. Бзежинський у 2011 р., на зустрічі у Нормандії під час отримання премії Алексіса де Токвіля, виголосив промову, в ході якої зазначив, що послаблення традиційних політичних важелів управління суспільними процесами, різкі соціально-економічні контрасти та розриви у суспільстві, становлять смертельну загрозу для трансатлантичного світу, еліти якого мають об'єднатися під безумовним домінуванням США. Таким чином, буде подоланий «національний егоїзм», що дозволить відмовитися країнам від частини суверенітету на користь спільного блага 24.

Проте, реструктуризація геополітичного простору та ствердження нових силових центрів змушують США поступово відмовитися від амбіцій єдиної наддержави на користь збереження лідерських позицій, що простежується у зовнішньополітичних настановах адміністрації Д. Трампа. На відміну від свого попередника, чинний президент США не акцентує принципову увагу не збереженні лідерства як такого 25. Проте, у Стратегії національної безпеки (2017р.) підкреслюється вагомість відродження американської могутності зсередини шляхом зміцнення економічної, космічної й енергетичної галузей, а також розвитку технологій, що має забезпечити національні інтереси США та створити приклад для наслідування іншими державами 26.

Отже, гегемоністські амбіції США $є$ історично зрозумілими, проте безперспективними через постійну трансформацію міжнародної системи та піднесення нових центросилових акторів. Ідея обраності англосаксонської раси та вищого призначення Америки, або США, як концепту рівності, справедливості, сили та неосяжних можливостей, залишається невід'ємною частиною самоідентифікації американців, про що свідчать публічні звернення президентів та офіційні документи. Таке переконання $€$ причиною колишніх американських тенденцій до світової гегемонії та вимушеної зміни пріоритетів на користь глобального лідерства, яке закріплюють сучасні стратегії національної безпеки США.

\footnotetext{
21 Погорська I.I. США: місія здійснима? Праксеологія творення глобального світу: монографія. Ін-т світ. економіки і міжнар. відносин НАН України. Київ: Грамота, 2009. 502 с.

22 National Security Strategy. Washington, D. C.: The White House, 2010. P. 8.

${ }^{23}$ Худолій А.О. «Перезавантаження» риторики Б. Обами // Гілея: науковий вісник. 2014. Вип. 82. C. 447-452.

${ }^{24}$ Zbigniew Brzezinski receives Jury du Prix Tocqueville Prize, October 14, 2011 // Washington, D. C.: CSIS: The official website. URL: https://www.csis.org/analysis/zbigniew-brzezinski-receives-jury-duprix-tocqueville-prize

25 Тихоненко І.В. Стратегія національної безпеки США як інструмент підтримки глобального лідерства та міжнародного порядку за адміністрації Б. Обами та Д. Трампа // Політичне життя. 2018. Вип. 1. С. 160.

26 National Security Strategy of the United States of America 2017, December 2017. 56 p. // The White House: The official website. URL: https://www.whitehouse.gov/wpcontent/uploads/2017/12/NSSFinal-12-18-2017-0905.pdf
} 


\section{REFERENCES}

Bogaturov, A.D. (Ed.). (2009). Sovremennaia mirovaia politika: Prikladnoi analiz [Modern world politics: Applied analysis]. Moskva: Aspekt Press [in Russian].

Carney, J. (2015). Nation of killers: Guns, violence, white supremacy: The American Dream become delusion. US: Lulu Press, Inc.

Draper, R.P. (1997). D. H. Lawrence: The critical heritage. UK: Psychology Press.

Dudko, I. (2005). Formuvannia bahatopoliusnoho svitu $\mathrm{v}$ umovakh post bipoliarnosti: Prohnozy i realii suchasnykh mizhnarodnykh vidnosyn [Formation of a multipolar world in a post-bipolarity: Forecasts and realities of the modern international relations]. Suchasna ukrainska polityka. Polityky i politolohy pro nei, 5. Retrieved from http://lib.chdu.edu.ua/pdf/pidruchnuku/21/44.pdf [in Ukrainian].

Fesenko, M. (2016). Perspektyvy zberezhennia liderstva SShA v postbipoliarnii mizhnarodnii systemi [Prospects for maintaining the U.S. leadership in the post-bipolar international system]. Amerykanska istoriia ta polityka, 2, 31-37 [in Ukrainian].

Kennedy, P. (1987). The rise and fall of the great powers. Economic change and military conflict from 1500 to 2000. New York: Random House.

Khudolii, A.O. (2014). «Perezavantazhennia» rytoryky B. Obamy [«Reboot» of B. Obama's rhetoric]. Gileya: naukovyi visnyk, 82, 447-452 [in Ukrainian].

Lloyd, G.D. (1938). The truth about the peace treaties. Vol. 1. London: Victor Gollancz.

Lomtev, A. (2011). Evoliutsiia kharaktera mirovogo poriadka i vneshnepoliticheskikh strategii ego formirovaniia $v$ amerikanskoi politicheskoi nauke [The evolution of the world order nature and the foreign policy strategies of its formation in American political science] (PhD dissertation). Moskovskii aviatsionnyi institute, Moskva [in Russian].

Marcus, J. (1998). Adjustment, recrimination: Franco-US relations and the new world disorder. The Washington Quarterly, Spring, 17-31.

Mironova, M.A. (2007). Transformatsiia vidnosyn Yevropeiskoho Soiuzu ta SShA $v$ postbipoliarnyi period [Transformation of relations between the European Union and the United States in the post-bipolar period] (Candidate's thesis). Kyiv [in Ukrainian].

Panarin, A. (2000). Glava III: Amerikanskii globalizm [Chapter III: American globalism]. In Agenty globalizma. Moskva [in Russian]. Retrieved from http://www.patriotica.ru/books/panar_agents/part1_3.html

Pohorska, I. \& Lakishyk, D. (2011). Zovnishnia polityka administratsii B. Obamy v konteksti amerykanskoho hlobalnoho liderstva [The Obama Administration's foreign policy in the context of American global leadership]. Problemy mizhnarodnykh vidnosyn: Zbirnyk naukovykh prats, 2, 179-192 [in Ukrainian].

Pohorska, I.I. (2009). SShA: Misiia zdiisnyma? Prakseolohiia tvorennia hlobalnoho svitu [The USA: Is a mission possible? Praxeology of the global world creation]. Kyiv: Hramota [in Ukrainian].

Shakleina, T. (2015). Liderstvo i sovremenn i mirovoi poriadok [Leadership and the modern world order]. Mezhdunarodnye protsessy, 4 (43), 6-19 [in Russian].

Sherhin, S. \& Fesenko, M. (2009). Transformatsiia vzaiemodii mizhnarodno-politychnykh aktoriv $\mathrm{v}$ umovakh poslablennia hlobalnoho liderstva SShA [Transformation of the international political actors' interactions in conditions of the global U.S. leadership weakening]. Naukovyi visnyk dyplomatychnoi akademii Ukrainy, 16, 346-355 [in Ukrainian].

Tykhonenko, I.V. (2018). Stratehiia natsionalnoi bezpeky SShA yak instrument pidtrymky hlobalnoho liderstva ta mizhnarodnoho poriadku za administratsii B. Obamy ta D. Trampa [US National Security Strategy as a tool for supporting global leadership and international order (B. Obama and D. Trump)]. Politychne zhyttia, 1, 158-163 [in Ukrainian].

Weston, Ch. (1997). Key US foreign policy interests. Aussen Politik, 1 (48), 49-57. 


\author{
Margaryta Lymar \\ (Petro Mohyla Black Sea National University, Mykolaiv, Ukraine) \\ ORCID: https://orcid.org/0000-0001-9902-2709
}

\title{
Origins and Evolution of the Concept of the United States Global Leadership
}

The basic principles of the concept of the United States global leadership are disclosed in the paper, its initiation as a concept of world hegemony and evolution to a more moderate position taking into account the world transformational processes. The goal of the paper is to study the origins of the concept of global US leadership since the end of the $19^{\text {th }}$ century and its implementation in the foreign policy of the state.

The ability of the US to make a qualitative impact on global geopolitical processes is analyzed. It is proved that the American nation is characterized by a special self-identification that verges on the feeling that the American nation is chosen by God. The US, accordingly, is perceived as a state with a special mission. It is ascertained that the aspiration of the United States to the world leadership lies in the theories of the exclusiveness of the Anglo-Saxon race, which has the right to expand and spread its own state and social system in the world. Expansion theory gained strength from the second half of the $19^{\text {th }}$ century. At the same time, the constant evolution of the international system, the entrance of new actors in the world arena forced the United States to reconsider foreign policy directives and «agree» on the role of a world leader.

After the period of Bloc confrontation, in particular, at the beginning of the $21^{\text {st }}$ century, the United States refuses to encroach on the role of the world hegemon and concentrates on leading the world community as «the first among equals». The course towards the achieving and preservation of world leadership was consolidated in Barack Obama's foreign policy taking into consideration the fact that the US possesses the potential of «hard power» that is able to physically control the weaker countries; it is characterized by economic power, which is the source of the general might of the state; and it is able to exert their ideological influence by using «soft power», which is based on the leader's diplomatic arsenal. Thus, it has been confirmed that the United States has never renounced the global domination, but taking into account the transformational changes in the international system, it has chosen the course towards the achieving and preservation of global leadership as a better alternative to world hegemony.

Keywords: USA, leadership, hegemony, concept, «New World» 